\title{
Business Groups Exist in Developed Markets Also: Britain Since 1850
}

\section{Citation}

Jones, Geoffrey. "Business Groups Exist in Developed Markets Also: Britain Since 1850." Harvard Business School Working Paper, No. 16-066, November 2015.

\section{Permanent link}

http://nrs.harvard.edu/urn-3:HUL.InstRepos:24009687

\section{Terms of Use}

This article was downloaded from Harvard University's DASH repository, and is made available under the terms and conditions applicable to Open Access Policy Articles, as set forth at http:// nrs.harvard.edu/urn-3:HUL.InstRepos:dash.current.terms-of-use\#OAP

\section{Share Your Story}

The Harvard community has made this article openly available.

Please share how this access benefits you. Submit a story. 


\section{Business Groups Exist in Developed Markets Also: Britain since 1850}

Geoffrey Jones

Working Paper 16-066 


\section{Business Groups Exist in Developed Markets Also: Britain Since 1850}

\section{Geoffrey Jones}

Harvard Business School

Working Paper 16-066 


\title{
Business groups exist in developed markets also: Britain since 1850
}

Geoffrey Jones

Harvard Business School

November 2015

\begin{abstract}
Diversified business groups are well-known phenomenon in emerging markets, both today and historically. This is often explained by the prevalence of institutional voids or the nature of government-business relations. It is typically assumed that such groups were much less common in developed economies, and largely disappeared during the twentieth century. This working paper contests this assumption with evidence from Britain between 1850 and the present day. During the nineteenth century merchant houses established business groups with diversified portfolio and pyramidal structures overseas, primarily in developing countries, both colonial and independent. In the domestic economy, large single product firms became the norm, which over time merged into large combines with significant market power. This reflected a business system in which a close relationship between finance and industry was discouraged, but were there few restrictions on the transfer of corporate ownership. Yet large diversified business groups did emerge, which had private or closely held shareholding and substantial international businesses. The working paper argues that diversified business groups added value in mature markets such as Britain. In the domestic economy, Pearson and Virgin created well-managed and performing businesses over long periods. The much-criticized conglomerates of the 1970s-1990s era such as Hanson and BTR were also quite financially successful forms of business enterprise. The demise of many of them appears to owe at least as much to management fads as to serious financial under-performance.
\end{abstract}




\section{Business groups exist in developed markets also: Britain since $1850^{1}$}

\section{Introduction}

Business groups, defined as a constellation of legally-independent companies bound together with formal and/or informal ties, are well-known to be a prevalent form of business enterprise across much of contemporary Asia, Latin America and the Middle East. (Colpan, Hikino, and Lincoln, 2010). A body of competing theories has developed to explain them. Market imperfections theory has explained them as responses to the institutional voids that are commonly found in emerging markets. (Khanna and Yafeh, 2007) Political scientists have emphasized the role of government policies in targeting particular industries and sectors, and giving special privileges to selected business group. (Schneider, 2010) An emerging body of literature employing evolutionary perspectives has identified the role of entrepreneurship (Kock and Guillen, 2001, Chung 2006, Jones and Colpan 2016). Business historians have shown that the business group form, contrary to early research which related it primarily to the post World War 2 era, have demonstrated the business groups became pre-eminent in the second half of the nineteenth and early twentieth centuries in many non-Western economies, including Argentina,

\footnotetext{
${ }^{1}$ I would like to thank Ann-Kristin Bergquist, David Collis, Asli Colpan, and the participants at a conference on "Business Groups in the West" held in Kyoto on March 8-10 2014, for helpful comments on earlier drafts of this working paper. A version of this working paper will appear in Asli Colpan \& Takashi Hikino (eds), Business Groups in the West, Oxford: Oxford University Press, forthcoming.
} 
Chile, India, Japan, Mexico and Turkey. (Tripathi 2004, Jones 2005a, Barbero and Jacob 2008, Jones and Lluch 2015,Jones and Colpan 2016).

In contrast, the existence of business groups in the developed West has been much less studied, with the conspicuous exception of Sweden, where diversified business groups such as the one owned by the Wallenberg family have been highly influential for over a century. (Glete 1994, Lindgren 1994, Iversen and Larsson, 2011) Business groups used to play no role in the standard accounts of the business history of Britain. In the classic story told by Alfred D. Chandler (and many others), the United States raced ahead of Britain as the world's largest economy in the late nineteenth century because it created large industrial corporations which separated ownership from control, created managerial hierarchies and eventually the M-form, and undertook the necessary investments in the new capital-intensive investments of second industrial revolution such as machinery and chemicals. The British, in contrast, remained committed to family ownership and management, which preferred short-term income to longterm growth in assets, and had a bias for small-scale operations which contributed to failures to invest and modernize. Consequently, the British economy was seen as "failing." The major research question was why Britain did not follow the American path of creating big firms with professional managers which was assumed to be the "one best way." (Chandler, 1990; Elbaum and Lazonick, 1987; Hannah, 1976).

Today little remains of this interpretation. The United States had higher productivity than Britain (or anywhere else) by the mid-nineteenth century, for reasons other than business structures, while Britain had a clear productivity lead over its European counterparts until the 1950s, and again between the 1980s and the 2000s. Nor would many scholars now view family 
ownership as inherently inferior to professional management. There appears to be no correlation between the adoption of US-style managerial hierarchies and productivity performance in the interwar years. (Jones 1997, Broadberry and Crafts 1992)

In any case, revisionist research has now suggested that it was the United States rather than Britain that large industrial corporations clung to family business. In 1900, according to Hannah, it was US business corporations where were dominated by plutocratic family owners, while British quoted companies showed higher levels of divorce of shareholding owners from management controllers (Hannah, 2007). In 2012 Foreman-Peck and Hannah showed that the divorce of ownership and control in British public companies was far ahead of any other country, and especially the United States. (Foreman-Peck and Hannah, 2012).

During the interwar years, and again during the 1960s, there were major merger waves in British industry. By 1958 the share of the 100 largest enterprises in manufacturing net output was higher in Britain than in the United States (32 versus 30 per cent). By 1970 Britain was far more concentrated by this measure than the United States (41 versus 33 per cent). By that year the Mform was also almost as widespread as in the United States (Jones 1997; Whittington and Mayer 2000). Although the 1970s saw a period of structural dislocation, as major industries such as automobile manufacturing experienced major crises, subsequently there was a major renaissance of British business and the British economy, based fundamentally on an embrace of globalization and a strong shift from manufacturing to higher value-added services. (Owen, 2009). It was only during and after the global financial crisis beginning in 2008, which adversely affected an economy which was extremely exposed to global financial flows, that some downsides of this shift were observed. Certainly the British-owned manufacturing sector was quite small. In 2014 
the four British-headquarted companies among the largest firms were the oil company BP (no 6), the retailer Tesco (no 63), and the two banks HSBC and Lloyds (77 and 94, respectively) The largest manufacturing company was the Anglo-Dutch consumer products company Unilever, ranked 140 (Fortune 2014)

It is within these radical shifts in the overall interpretation of what happened to British business from the nineteenth century that the role of business groups has surfaced. The first mention of business groups in the British business history literature was only in the 1990s (Jones, 1994; Jones and Wale, 1998). However it is now well-understood that much British foreign direct investment (hereafter FDI) before 1914 was conducted by business groups which had a striking resemblance to the business groups found in Asia and Latin America today, debunking any view that they were the exclusive preserve of post-colonial developing countries. Much less research, however, has yet been done on the role, if any, of diversified business groups in the domestic economy. However this working paper shows that they were also not absent.

For the sake of clarity, the following sections separate out the international and domestic stories of British business groups, while noting some commonalities in their growth and development.

\section{British Business Groups in Global Business: 1850-1970}

From the mid-nineteenth century the world economy globalized. Thousands of firms, mostly based in Western countries which had experienced the Industrial Revolution, crossed 
borders and established operations in foreign countries. In 1914 world FDI amounted to \$14.6 billion (\$225 billion in 2015 US dollars), or the equivalent to 9 percent of world output, a ratio not seen again until the 1990s. Britain alone was the home economy of nearly one half of this FDI. (Jones, 1994; Jones 2005a; Dunning and Lundan, 2008)

British FDI took a variety of corporate forms. In manufacturing, modern-style multinationals were the dominant form. Firms such as Dunlop in rubber manufacturing and J \& P Coats in cotton thread, first built businesses at home, and then established wholly-owned manufacturing affiliates in other European countries and/or the United States. They were single product firms. (Jones, 1986) In contrast, much FDI in natural resources and services took the form of large diversified business groups organized around core merchant houses or trading companies. (Jones, 2000; Jones and Colpan, 2010)

British trading companies grew rapidly to exploit commercial links between their home country and the colonies as well as other developing countries. They perceived that large profits were to be earned from the exploitation of, and trade in, natural resources. The lack of infrastructure and local entrepreneurship in developing countries meant, first, that trading companies had to invest themselves rather than rely on others to create complementary businesses, and second that there were numerous profitable opportunities which could be exploited as the borders of the international economy and of empires advanced.

The general pattern of diversification before 1914 was from trade to related services such as insurance and shipping agencies, to FDI in resources, and processing in developing host economies. The British trading companies made the largest investments in tea, rubber and sugar 
plantations, and teak. Chilean nitrates, Indian coal, and petroleum were also the recipients of considerable investment. As merchants, they were not especially interested in "locking up" capital in manufacturing, but they did make substantial investments in cotton textile and jute manufacture, sugar refining, and flour milling.

Multiple factors exercised systematic influences on the diversification strategies of the British trading companies in this era. The opportunities for scope economies and the incentive to reduce transactions costs is the first one. The boom in commodity prices in the first global economy created lucrative entrepreneurial opportunities. A third influence was the expansion of imperial frontiers which reduced the political risk of investing in Africa and Asia. (Jones, 2000)

Finally, and importantly, there was capital availability arising from Britain’s booming capital exports from the 1870s. As the merchant houses expanded, they floated on the stock exchange legally independent firms, subsequently described by the business historian Mira Wilkins as "free-standing firms, which they continued to control through small equity holdings, management contracts and other means in the established tradition of "agency houses". (Wilkins, 1988) They functioned, then, as venture capitalists identifying opportunities and placing potential British investors in touch with them.

Retrospectively, it might seem surprising that they could access equity. The legal structure for shareholders was not robust by later standards, as basic financial statements were unavailable even to shareholders and minority shareholder protection was inadequate. It was not until the Companies Act of 1929 that it was stipulated in the case of British public companies that balance sheets should be sent to all shareholders prior to the annual general meeting, and not 
until 1948 that it stipulated that the profit and loss account also had to be circulated. However despite such information asymmetries, there were sufficient mitigating factors, including stock market regulations and extensive public financial information in the news media, to provide the assurances that enabled a large growth in individual share ownership. The number of individual investors on holding securities on the London Stock Exchange grew from 250,000 to one million between 1870 and 1914. There were also institutional investors, as commercial banks, insurance companies and investment trusts shifted their portfolios into stocks and shares. Overall Britain had by far the largest equity market in the world. (Cheffins, 2008; Michie, 1999). Insofar as companies engaged in commodities and other businesses in distant countries might be considered as particularly risky, the association of a reputable trading company with a new company provided some assurance to investors of honest and competent management. (Jones, 2000)

Table 1 shows the geographical spread of some of the larger British international business groups in 1914 . 
Table 1 Geographical Location and Parent Capital Employed of Selected Large British International Business Groups, 1913

\begin{tabular}{|l|l|l|l|}
\hline Parent Merchant & $\begin{array}{l}\text { Estimated Capital } \\
\text { Employed } \\
(£ 000 \mathrm{~s})\end{array}$ & $\begin{array}{l}\text { Major Host Countries } \\
\text { Regions }\end{array}$ & Other Operations \\
\hline Jardine Matheson & 2,500 & China & $\begin{array}{l}\text { Japan;USA;South Africa; } \\
\text { Peru }\end{array}$ \\
\hline Williamson & 2,000 & Chile; USA & Peru;Canada \\
\hline Wilson Sons \& Co & 1,728 & Brazil; Argentina; UK & Tunisia;Senegal; Egypt \\
\hline James Finlay & 1,500 & India; UK & Ceylon;USA;Canada;Russia \\
\hline Anthony Gibbs & 1,500 & Chile;Peru;Australia;UK & USA \\
\hline Harrisons $\&$ & 1,226 & Malaya;Dutch East & Ceylon;USA: Canada; \\
Crosfield & & Indies;India & Australia; New Zealand \\
\hline Dodwell \& Co & 225 & China;Canada;USA & Ceylon;Japan \\
\hline
\end{tabular}

Source: Jones (2000), pp. 54, 55, 58-61

\subsection{Organizational forms of international business groups}

In the diversified business groups which emerged around the British merchant houses, the merchant house would act as the core firm within each group, usually responsible through its 
overseas branches for trading and agency business, while separately quoted or incorporated affiliates — often not wholly owned — were engaged in plantations, mines, processing, and other non-trading operations. Consequently, although reinvested profits continued to be an important source of funds for the British merchant groups, after 1870 they also drew substantially on outside funds to finance expansion into new activities.

There were several organizational forms. First, there were "unitary" business groups in which activities were wholly owned, although this did not mean that they were integrated in the sense of a modern corporation. A second, "network", form consisted of a core trading company with multiple wholly owned branches surrounded by a cluster of partly owned firms linked not only by equity, but also debt, management, cross directorships, and trading relationships. Balfour Williamson was one example. It is this type that most resembles the business groups in today's emerging economies. Tables 2.1 and 2.2 show the organizational structure of Balfour Williamson in 1914. 
Table 2.1 Balfour Williamson Group, 1914:Wholly-Owned Partnerships

\begin{tabular}{|c|c|c|c|}
\hline $\begin{array}{l}\text { Wholly Owned } \\
\text { Partnerships }\end{array}$ & Country & Date Opened & Activities \\
\hline $\begin{array}{c}\text { Balfour } \\
\text { Williamson }\end{array}$ & UK & 1851 & Head office \\
\hline $\begin{array}{c}\text { Williamson } \\
\text { Balfour }\end{array}$ & Chile & 1852 & Selling and managing \\
\hline Williamson \& Co. & Chile & 1911 & Nitrates, grain milling \\
\hline Milne \& Co & Peru & 1912 & Oil company agents \\
\hline Balfour Guthrie & United States & 1869 & $\begin{array}{c}\text { Selling, managing, } \\
\text { land }\end{array}$ \\
\hline Balfour Guthrie & Canada & 1911 & $\begin{array}{c}\text { Trading fish, } \\
\text { newsprint, wood pulp }\end{array}$ \\
\hline
\end{tabular}

Table 2.2 Balfour Williamson Group, 1914: Principal Affiliates

\begin{tabular}{|c|c|c|c|c|}
\hline Principal & Country of & Date Started & \% equity held by & Activities \\
Affiliates & Registration & & parent & \\
\hline Pacific Loan and & UK & 1878 & Majority & Mortgage loans; \\
Investment Co, & & & & farms in \\
\hline
\end{tabular}




\begin{tabular}{|c|c|c|c|c|}
\hline & & & & California \\
\hline $\begin{array}{c}\text { Balfour Guthrie } \\
\text { Investment }\end{array}$ & USA & 1889 & Majority & $\begin{array}{l}\text { Investment } \\
\text { company }\end{array}$ \\
\hline W.F. Stevenson & Philippines & 1904 & 25 & Trading \\
\hline Lobitos Oilfields & UK & 1908 & Minority & Peruvian Oil \\
\hline $\begin{array}{c}\text { Sociedad } \\
\text { Comercial } \\
\text { Harrington } \\
\text { Morrison }\end{array}$ & Chile & 1910 & 75 & $\begin{array}{c}\text { Trading in north } \\
\text { Chile }\end{array}$ \\
\hline $\begin{array}{c}\text { West Coast Oil } \\
\text { Fuel }\end{array}$ & USA & 1911 & 30 & $\begin{array}{c}\text { Oil storage in } \\
\text { Chile }\end{array}$ \\
\hline $\begin{array}{c}\text { Olympic } \\
\text { Portland Cement }\end{array}$ & UK & 1911 & 1 & $\begin{array}{c}\text { Cement Plant, } \\
\text { Washington } \\
\text { state, USA }\end{array}$ \\
\hline $\begin{array}{l}\text { Crown Mills } \\
\text { Corporation }\end{array}$ & USA & 1911 & 100 & $\begin{array}{c}\text { Flour Mills, } \\
\text { Portland, Oregon } \\
\text { USA }\end{array}$ \\
\hline $\begin{array}{l}\text { Santa Rosa } \\
\text { Milling Co }\end{array}$ & UK & 1913 & 45 & $\begin{array}{l}\text { Flour Mills, } \\
\text { Chile and Peru }\end{array}$ \\
\hline $\begin{array}{c}\text { Sociedad } \\
\text { Molinero de } \\
\text { Osorno }\end{array}$ & Chile & 1913 & 100 & Flour Mill, Chile \\
\hline
\end{tabular}


Source: Jones (2000), pp. 168-169.

A variant of this type, which might be called a "loose network", had no corporate core beyond family shareholdings. This was the case of a cluster of trading and shipping firms owned by the Inchcape family, which only began to consolidate after 1948 (Munro 2003; Jones 2000)

The choice of organizational form was determined in part by the business portfolios of companies. Trading operations and acting as agents for shipping, insurance, and manufacturing firms were generally internalized. These activities required either a large knowledge base on the part of firms, or the maintenance of a sound reputation among actual or potential clients. Trading companies whose business consisted primarily of trading and shipping agency and other agency work were mostly organized on a unitary basis. Within "network"-type business groups, these activities were also the responsibilities of wholly owned branches, but investments in plantations, mines and other diversified activities were typically placed in independent companies. Merchants made their profits from commissions on trade and agency business. As a result, they sought access to trade flows and information, and to prevent being denied access by being bypassed by parties they had brought together. Outright ownership of mines and plantations was, as a result, unnecessary as sufficient access was secured by non-equity modes.

If ownership of non-“core” activities could be shared, there were other advantages. It limited the risks of the parent trading companies, while enabling outside capital to be bought into ventures. This permitted the use of other people's money to undertake entrepreneurial investments designed to generate new sources of income for them through commission and fees. 


\subsection{Competences and Longevity of International Business Groups}

How can the competences of these business groups be assessed? Evidently they were initially the beneficiaries of a home country advantage. They developed at a time when Britain dominated world trade flows and, by the late nineteenth century, world capital flows. They were able to access the world's largest equity markets. Many of their investments were located within the British Empire or parts of Latin America under British informal influence. In the interwar years the merchant firms were able to protect their business through extensive collusive cartels supported by the colonial authorities. Although Britain's relative importance in the world economy began to decline from the late nineteenth century, the British trading companies in Asia, and Africa continued to benefit from the umbrella of British colonial rule through until the 1950s and even later in the case of Hong Kong, Bermuda and other offshore financial territories including the Cayman Islands and the British Virgin Islands.

The historical longevity of the trading companies in their host regions and the colonial status of many of these countries resulted in multiple "contacts" which provided a major competitive advantage. British colonial officials were frequently critical of the merchant firms, and certainly did not protect them against competitors. But if colonial administrations had their own agendas, they were still sufficiently close to the merchant firms in their ideological and cultural outlook to provide an immensely supportive context. However business groups also established long-standing “contacts” with local business elites in Asia, Africa, and Latin America which gave them a "quasi-local” status. They also had core competences centered on the areas 
of knowledge, information, and external relationships. Management systems which involved staff spending their entire careers abroad generated extensive tacit knowledge about regions, products, and marketing channels. (Jones 2000; Jones and Colpan, 2010)

The constellation of firms around the trading companies were linked by multiple institutional and contractual modes, with flows of managerial, financial, and trading relationships among those. The business groups possessed advantages related to imperfections in capital, labor, and product markets and in the area of property rights enforcement. There were numerous conflicts of interest and potential for opportunist behavior, but in practice rent-seeking was restrained. The external relationships surrounding the trading companies were also important elements of their architecture. These networks often relied on trust rather than contracts and were extremely durable. British merchants emerged from hubs such as London, Liverpool, and Glasgow and clustered in hubs overseas, and this provided one support for the high trust levels which facilitated such networks. Long-term relationships with banks provided a source of credit for routine operations, and support during crises. (Jones, 2000; Jones and Colpan, 2010)

The overall robustness of the business groups created before 1914 was demonstrated by their longevity. The subsequent decades were a difficult time for international business in the face of the exogenous shocks of world wars and the Great Depression, and the resulting policy responses in the shape of tariffs and exchange controls. After 1931 the global economy disintegrated. There was reduced diversification, yet most of the business groups persisted, sometimes because family and other shareholders were prepared to sustain companies paying low or no dividends. Many of the firms had all or most of their business within the sheltered confines of the British Empire. They sometimes still benefited from fiscal and other privileges 15 
from colonial governments, while collusive cartels were permitted and usually supported. (Jones, 2000)

After 1945 the British business groups continued to diversify and "reinvent" themselves. General and produce trading gave way to more specialized trading and sales agencies. Firms diversified geographically, while the Inchcape group relocated itself out of India towards the faster-growing and more open economies further east. New business groups emerged. After Tiny Rowland became chief executive of Lonrho, a company which began operating in Africa in 1909 as the London and Rhodesian Mining Company, he transformed the company into a major business group. By 1995, Lonrho’s African non-mining businesses had expanded into 15 sub-Saharan African countries, with 90 operating companies involved in a wide range of business activities.

In the post-war decades, constraints were often more political than financial. Leaving aside such 'havens' as Hong Kong, where two important merchant houses established in the nineteenth century, John Swire and Jardine Matheson, were based, the general thrust of public policy in most developing host economies was to restrict or prohibit FDI, especially in natural resources and services. Among the most successful trading companies were firms which had suffered traumatic "shocks" as a result of the Pacific War and the Chinese revolution. The British merchants in the Far East and South East Asia acquired new premises and facilities which probably improved their efficiency compared with the prewar period, but more importantly their losses stimulated an entrepreneurial urge to rebuild and renew their businesses. Motivation of this type was lacking perhaps among the British business groups active in India and South 
America, whose owners and managers seemed resigned to slow decline because of political hostility.

For the most part the basic organizational pattern of the network form of business groups as they had developed by the early twentieth century remained in place until at least the 1960s. The creation of new affiliate firms to undertake non-trading activities continued. After 1929, British exchange controls on investments outside the Sterling Area as well as the perceived risks of international investment effectively ended the flotation of new firms on the British capital markets. However well before then the trading companies had begun to make more use of locally registered firms or other types of institutional arrangement. The growing burden of British taxation on companies whose profits were earned largely abroad after World War 1 was initially an important consideration, and this led to the registration of several affiliated firms being shifted. It was really only in the 1960s that changes to this organizational form began to occur as improvements in corporate reporting and the emergence of organized capital markets in many countries meant that investors no longer needed the brand of a British trading company to guarantee that their savings would be "safe". Indeed, complex groups with cross-shareholdings and internal transfers of commission and fees within the group looked less attractive as shareholders changed from being atomistic individuals to institutional investors (in Britain) or powerful business elites (in Asia and elsewhere). (Jones 2000)

The postwar fate of the business groups was in part correlated with their main host regions. Some host regions became hostile to foreign firms or imposed penal rates of taxation. This happened to the British business groups in South Asia and Latin America. East and South East Asia and West Africa, at least through to the 1970s,—offered much greater prospects. Hong 17 
Kong from the 1950s, which combined fast economic growth with low taxes and a British legal system, offered especially favorable conditions. However strategic choices were possible. Swire's and Jardine's survived the loss of their Chinese investments in 1949. Inchcape and Booker McConnell both successfully escaped from "difficult" host countries to more attractive areas. And while overall political and economic conditions in Africa deteriorated from the perspective of Western firms from the 1960s, Lonrho developed as a large business group in this period. (Jones, 2000)

The fate of the business groups was also related to the stability of their shareholding structure. In a considerable number of cases, the decision by family shareholders to sell their shareholding was the catalyst which ended the independent existence and/or British ownership of firms. The development of a more fluid market for corporate control in Britain from the 1950s meant that the vulnerability of firms to takeover was much greater. (Jones, 2000) Regulatory changes, especially the London Stock Exchange’s 1967 code on take-overs which required any one acquiring 30 per cent of a listed firm to buy 100 per cent also made it much more difficult to retain a networked, or pyramidal, corporate structure. (Morck, 2009)

Against this background, in the 1970s especially, diversification strategies focused on "redeployment" from high-risk developing to developed countries such as the Commonwealth countries, including Britain, and the United States. In retrospect, it is apparent that British managements were prone to exaggerate the risks caused by political change in the developing world, while some firms also misjudged their core competences by acquiring firms in new industries and countries where they had no advantage and could add no value. Yet successful transitions were made from traders and plantation owners in developing economies to 
manufacturers or distributors in developed countries. The British merchant houses in the Far East and South East Asia rose from the ashes of the wartime destruction of their assets and built vibrant new businesses, becoming large-scale automobile distributors and even the owner of a major airline in the case of Swire's and Cathay Pacific. However, the British business groups in India and Latin America were notably unsuccessful in finding new strategies to fit changing circumstances.

\section{The Disappearance of the International Business Groups}

During the 1980s the major British business groups continued to be quite successful. A study of the post-tax returns on net capital employed between 1980 and 1989 showed Booker at 21.3 per cent; Inchcape 12.9 per cent; Swire’s 12.7 per cent; Jardine Matheson 10 per cent; and Lonrho 9.2 per cent. The equivalent figures for BP were 12.1 per cent and Unilever 10.7 per cent. (Jones, 2000: 328) Yet by the following decade many of these long-standing business groups had begun to be transformed into focused food companies (Booker Group), automobile distributors (Inchcape), or chemical companies (Harrisons \& Crosfield, now Elements). Of the surviving British trading companies, Swire's and Jardine Matheson continued in business as large and ultimately British-controlled multinational business groups primarily active in Asia.

What caused the overall decline of most of these business groups? The first challenge arose from further changes in the economic and political environment of important host economies. Jardine Matheson and Swire have continued to draw enormous advantage from their position in Hong Kong. Conversely the fate of the giant United Africa Company (UAC), owned by Unilever, was all but sealed by the economic and political turbulence of the West African, and 
especially the Nigerian, economies from the 1970s, as well as the growing level of corruption which was increasingly difficult for its parent Unilever to control. (Fieldhouse, 1994) In Malaysia and elsewhere, the British business groups were driven out by government determination to take local ownership of natural resources. (Yacob \& Khalid, 2012).

Secondly, some business groups fell victim to failed attempts to diversify into regions and industries where they lacked expertise. Returns on capital employed in the 1990s fell at Inchcape, Swire's and Lonrho, though they rose at Jardine Matheson and Harrison's and Crosfield. The "merchant adventurer" ethos and the desire to escape from their traditional developing country hosts had led firms in some cases far away from core competences, however widely defined. During the 1980s many of these diversification strategies ran into great difficulties. The competence in region-specific knowledge and know-how was thus both a competitive advantage and a competitive disadvantage for the business groups, in that it provided a constraint on diversification options outside the host region. Extensive diversification outside "core" activities also proved to be detrimental thanks to the escalating costs from managerial constraints and diminishing benefits from the exploitation of established and proven expertise.

The final and the ultimate arbiter of the fate of the diversified business groups, however, was, however, the British capital markets. The capital markets which had made the creation of the diversified business groups possible before 1914 proved their nemesis from the 1980s. It was the declining share price of the publicly quoted firms which led to their ultimate demise as diversified trading companies. This was not due as a whole to poor performance, but rather of changed perceptions and priorities. The changed nature of British equity holders, which was different from before 1914 as individuals had been largely replaced by institutional investors 20 
such as investment banks and pension funds by the 1980s, played a major role in that end. (Cheffins, 2008) While the individual shareholders before 1914—and indeed arguably through to the 1970s — were passive and often long-term holders of stock, the institutional investors that replaced them later on viewed shares increasingly as short-term investment vehicles. They were responsible to the owners of the funds that they invested, and as such had a duty to maximize investment returns. Consequently the main preoccupation of the institutions was short-term financial performance and share prices. Institutional investors held their own diversified portfolios, and since the 1980s preferred individual firms to focus on their "core" areas enabling their performance and prospects to be more efficiently monitored. (Jones 2000, Jones 2005b)

The language of "core competence" and "sticking to one’s knitting” began to spread by business schools and management consultancies after 1980s, and in a sense became a selffulfilling prophecy which reduced the share prices of diversified firms in a way which the managers of publically quoted firms ignored at their peril. From the 1980s financial analysts became a major influence on corporate strategies. As Unilever, for example, discovered, they disliked complexity and acted as advocates of these fashionable management theories. (Jones, 2005b: 347-351) Analysts and fund managers benchmarked against industrial categories to compare price/earnings ratios. Business groups, like the conglomerates discussed below, did not fit this model. The chairman of Inchcape in the mid-1990s noted:

"I would not say the market was that confused about the businesses that Inchcape was in, but we were still seen as a bit of a conglomerate and conglomerates were completely out of fashion. Therefore, the market just refused to accept the intrinsic value of the company.” (Butler and Keary, 2000: 300). 
The ultimate family control of Swire's and Jardine Matheson ensured their survival. Both firms were sheltered from hostile host governmental pressures for localization during the 1980s, as the laissez-faire British colonial government in Hong Kong shared none of the protectionist and nationalistic sentiments of its neighbors in South Korea and Taiwan. The controlling families also took steps to consolidate their ownership of their multiple affiliates in response to occasional attempts by outside groups to take large equity stakes. As early as 1974 Swire placed most of its Hong Kong affiliates into a partly owned but publicly quoted (in Hong Kong) holding company, Swire Pacific, which in turn held equity in the principal affiliates, including Cathay Pacific and Swire Properties. At that time John Swire \& Sons directly held 50 per cent of the China Navigation Company, the major shipping subsidiary which was British-registered, and in 1976 the firm acquired the remaining 50 per cent of the equity. Most of the other affiliates remained partly owned, different classes of shareholding meaning that full control remained in the hands of John Swire \& Sons, itself still wholly owned by the founding families. John Swire \& Sons employed 122,000 persons in 2014.

Swire’s “twin”, Jardine Matheson, employed 240,000 persons by 2014, and controlled businesses with $\$ 61.5$ billion in revenues. The firm's interests ranged from the Mandarin Oriental hotel chain in Hong Kong to property development in China, supermarkets, construction, and car dealership. It owned more than half of Astra, the largest listed company in Indonesia, which itself has more than 170 companies. Jardine Matheson was noted for opaque governance and complex organizational arrangements. In 1984, following the announcement that Britain would return China to Hong Kong in 1997, it moved its domicile from Hong Kong to 
Bermuda. Ten years later, after Hong Kong refused to allow Jardine Matheson to use the protective takeover code of Bermuda, Jardine Matheson relisted its companies in Singapore.

\section{Business Groups and Domestic Business in Britain: 1850-1970}

The diversified business group organizational form was found much less frequently in British domestic business. The well-developed capital markets and the commercial banking system allowed single product firms, as the capital-intensity of industries at that time were not great. As firms grew in size, there were large-scale merger movements from the late nineteenth century. These were primarily horizontal. The fragmented cotton textiles industry, for example, saw numerous mergers: textiles accounted for 330 of the 895 firms affected by mergers between 1887 and 1900.(Hannah, 1976: 22) The Calico Printers' Association Ltd was formed in 1899 from the amalgamation of 46 textile printing companies and 13 textile merchants. The company at its inception accounted for over 80 per cent of Britain's output of printed cloth. In cotton thread, Britain’s largest cotton thread producer J \& P Coats went public in 1890, and six years later acquired four large competitors to create Britain’s largest industrial firm. Other mergers created the Salt Union, controlling 90 per cent of the domestic market, Associated Portland Cement (45 per cent of the market), Imperial Tobacco ( 90 per cent) and Distillers (75 per cent of the whiskey market).

These firms sometimes did not closely integrate merged firms, which were often managed as independent fiefdoms. In the literature they have often been described as federations of many specialized companies loosely presided over by holding companies, which were frequently

dominated by families and concentrated on certain industries. Imperial Tobacco, for example, 
remained a federation of family firms with little central direction. (Hannah, 1980: 53) In textiles, the leading firms Calico Printers Association, Bradford Dyers, and Fine Spinners and Doublers were seen by Chandler as characteristically loose federations of firms throughout the interwar years, although Hannah has recently denounced this view as one of Chandler's many “grotesque misclassifications” of British business history. In the case of Calico Printers, Hannah notes, the inefficient management organization was corrected within two years of the firm's formation. (Hannah, 2009: 33).

This dominance of specialist companies in the domestic economy contrasts with the unrelated diversification seen in some economies in Europe, and indeed with the British-based international trading companies. Compared to other countries at the time, institutional voids in financial and trading markets were low. The large equity market made it relatively easy and cheap for companies to raise capital. Whatever the risks arising from informational asymmetries, there was a large demand for shares, not least because shares in British-based companies outperformed returns in government bonds 34 out of the 43 years before 1914. Many local industrial companies floated their shares on provincial stock exchanges where knowledge about the individuals involved and the industry was well-known, greatly reducing the need for formal disclosure in company documents and annual reports. (Cheffins, 2008:205-220) Commodity markets were as well developed as financial markets.

The domestic market was compact and high income, and many firms were also prolific exporters in the highly globalized British economy. Absent any anti-trust legislation before 1948, specialist combinations could exercise substantial market power in their industries, so the financial incentives for unrelated diversification were hardly compelling, even if it was 
theoretically possible that they could reinvest the money earned from such monopolies to grow in unrelated industries. While international trading companies formed the core of the overseas business groups, Britain’s domestic banking system, which had become highly concentrated by 1914, did not provide an equivalent organizing driver for domestic business groups. In the highly developed and specialized British financial system, the equity and bond markets were perceived as the appropriate source of long-term funding, while the commercial banks provided short-term financial accommodation. This was the strong preference of the Bank of England also which promoted market-type relationships between banks and industries. Unlike bank-orientated economies such as Germany or Sweden, British banks did not take or hold large equity stakes in industrial firms, then, but instead focused on the provision of short-term finance or the floating of stock. It was striking that even for larger enterprises capital came from many sources, including re-invested profits, stock market issues, private placements with stockbrokers and insurance companies, and family. (Hannah, 1980:55)

The handful of business groups which did emerge typically had substantial international businesses, and purposeful entrepreneurial founders. A large group developed around the engineering contractor Weetman Pearson, which became one of the longest-lasting of such businesses in Britain. This began as a purely domestic business, but from the 1880s Pearson developed his business into a global contractor, undertaking massive infrastructure projects in the United States and Mexico. In 1901, he also began securing large oil concessions, and in 1909 found a hugely prolific oil well. Initially the main corporate vehicle was the contracting firm S. Pearson and Sons Ltd. After the discovery of oil, however, the Mexican oil assets were put into the Mexican-registered company Mexican Eagle Oil Company which had a primary listing in 
Mexico and a secondary listing in London. In 1912 the Eagle Oil Transport Co was registered in Britain to control the transportation and distribution of oil outside Mexico. Another British company, Anglo-Mexican Petroleum Company, marketed oil outside Mexico. A fourth company, Whitehall Securities Corporation, was founded in 1908 to manage S. Pearson and Son's other investments. Weetman Pearson closely controlled S. Pearson and Sons, which wholly-owned Whitehall Securities. Mexican Eagle had substantial outside shareholders in Mexico and Britain. Eagle Oil's ordinary shares were owned fifty/fifty by Mexican Eagle and S. Pearson, but the preference shares were listed. Anglo-Mexican was a private company. A recent study has estimated the market value of the entire group in 1919 at $£ 79$ million, which would have made it Britain’s largest business. (Bud-Frierman, Godley, and Wale, 2010; Garner 2011; Spender, 1930).

Pearson sold the Mexican oil business in 1919, but the business group expanded and continued to diversify both internationally and domestically. In Mexico and Chile it retained substantial electricity and tramway businesses, which were consolidated into a private British company Whitehall Electric Investments Ltd. in 1922. These were sold seven years later, but the company established new electricity businesses in Britain, and between 1925 and 1970 operated electricity and tramway business in Athens, Greece. It also established a new company, Amerada, for oil production in the United States. Although this was sequestrated by the British government during World War II, subsequently other oil investments were made in the United States and Canada. In 1969 these were rolled into a US oil company Ashland Oil and Refining Company, in which Pearson held a substantial equity stake. In 1919, the firm acquired a 45 per cent stake in the London branch of merchant bankers Lazard Brothers, and this became a 
majority stake in 1932. In 1921, Pearson purchased a number of local newspapers in Britain, which it combined to form the Westminster Press. This became the basis of a large publishing group. In 1957, the Group bought the Financial Times and acquired a 50\% stake in The Economist. It purchased the publisher Longman in 1968. Meanwhile in the early 1950s it acquired the Lawley Group, manufacturers, wholesalers and retailers of china and glass in Britain. Further acquisitions led in 1964 to formation of Allied English Potteries. During the 1960s the firm also bought a large shareholding in the French wine maker Château Latour. Pearson remained a family owned private company until 1969, when it floated 20 per cent of its equity on the London Stock Exchange and became a public listed company. It had five divisions of roughly equal profit contribution; banking and finance, investment trusts, newspapers and publishing, oil, and industrial. Table 3 lists the principal activities of the Group in 1969. 
Table 3 Pearson Group, c1969

\begin{tabular}{|c|c|c|}
\hline Company Name & Sector & \% Shareholding by Parent \\
\hline Whitehall Securities & Management and Financial & 100 \\
\hline Lazard Brothers & Investment Bank & 80 \\
\hline S. Pearson Publishers & Newspapers, Financial Times & 51 \\
\hline Westminster Press & Provincial British newspapers & 51 \\
\hline Longman Group & Book publishing & Majority \\
\hline Ashland Oil & Oil and chemical production, & Minority \\
& transport and distribution in & \\
\hline Standard Industrial Group & US, Canada, Indonesia, & \\
& BK manufacturing, including & \\
\hline Château Latour & pottery, glass, engineering & Majority \\
\hline Athens Pireas Electric & French wines & Majority \\
\hline \multirow{2}{*}{ Railways } & & \\
\hline
\end{tabular}

Sources; Hill (1985), Whittington and Mayer (2000); http://timeline.pearson.com;

http://www.gracesguide.co.uk/S._Pearson_and_Son

Pearson diversified much further after the public flotation, buying the famous London wax museum Madam Tussauds, amusement parks, investing in satellite broadcasting and much 
more. The Cowdray family trust retained a large, although no longer controlling, shareholding through the 1980s, and a family member remained as chairman as late as 1997. The diversification and the family investment, by then, made the business "an anomaly on the British scene,” albeit one that did not prevent it running large and successful businesses, including being "one of the world's leading financial publishers" (Whittington and Mayer, 2000, pp. 100-101; Hill, 1985). It was only in the late 1990s that diversification began to be unraveled, as financial analysts and markets increasing looked with disfavor on unrelated diversification. Madam Tussauds was sold in 1998, and the shareholding in the merchant bank Lazards in 2000. The company focused on educational publishing, newspapers and the media. In 2000 Pearson spent \$2.5 billion to acquire NCS, the largest American school testing company, and within a decade controlled three fifths of the U.S. testing market. Overall by 2015 Pearson had revenues of $\$ 8$ billion, 60 per cent of which were earned in the United States, and was the world's largest educational publisher. (Reingold, 2015). It was only in that year that Pearson divested its ownership of the Financial Times and The Economist.

Overall, during the post-World War II period the structure of British business changed radically. Family firms and family directors slowly disappeared. (Franks, Mayer and Rossi, 2005) Concentration increased at a rapid pace during the 1950s and 1960s with major merger waves. Large British companies adopted the M-form, frequently as a result of employing the services of management consultants, notably McKinsey. Channon's study traced the evolution of the M-form of organization for a sample of the ninety-two largest British companies from 1950 to 1970 (and ninety-six companies for the period 1960-1970). In 1950 he found only twelve companies in his sample had adopted a multidivisional structure. By the end of the 1950s some 
30 percent of the firms in the sample had such a structure, and by 1970 the M-form was the dominant organizational form, with sixty-eight of the ninety-six sample large British corporations adopting it. The spread of the M-form signaled the rapid expansion of product diversification in large British companies. By 1970 the M-form was almost as widespread in Britain as in the United States, while M-form had been more widely adopted in Britain than in any other large European economy. (Channon, 1973; Jones, 1997) Arguably that form served as a pre-condition for the growth of conglomerates.

\section{The Rise and Fall of Conglomerates: 1970 to the Present}

\subsection{The Growth of Conglomerates}

Table 4 shows the rapid rise in the share of unrelated diversified firms in the top 200 industrial firms in Britain between 1970 and 1993. 
Table 4 Diversification of Top 100 Industrial Firms in Britain (\%)

\begin{tabular}{|c|c|c|c|c|}
\hline & 1950 & 1970 & 1983 & 1993 \\
\hline Single Product & 24 & 6 & 7 & 5 \\
\hline $\begin{array}{c}\text { Dominant } \\
\text { Product }\end{array}$ & 50 & 32 & 16 & 10 \\
\hline Related & 27 & 57 & 67 & 61 \\
Diversified & & & & \\
\hline Unrelated & - & 6 & 11 & \\
Diversified & & & & \\
\hline
\end{tabular}

Source: Whittington and Mayer (2000), p.139

The growth of acquisitive conglomerates occurred in several waves. During the postwar decades a number of highly diversified conglomerates emerged, including Sears, Slater Walker, Thomas Tilling, and Reckitt and Coleman. The Rank Organization was particularly interesting. In 1937, Joseph Arthur Rank formed The Rank Organisation, bringing together a number of motion picture businesses acquired in previous years, including Pinewood Studios and Denham Films. Subsequently he added the Odeon chain of cinemas, the Gaumont-British Picture Corporation and the noted film studios at Elstree and Lime Grove. During the 1940s and 1950s, the Rank Organisation produced numerous films, but also engaged in unrelated diversification. In 1956, Rank entered into a joint venture with the Haloid Corporation of the USA to manufacture and market photocopying equipment under the name Rank Haloid. The company, which subsequently became known as Rank Xerox, was hugely successful (Rank finally sold its 
share in 1997). Rank also owned a record company, Top Rank Records (sold in 1960 to EMI) and manufactured radios and televisions through Rank Bush Murphy Group (sold in 1978 to Great Universal Stores). During the 1980s and 1990s Rank made numerous acquisitions in leisure retail sector, including theme parks, pubs, restaurants, nightclubs, hotels, holiday camps, timeshare developments and camping grounds as well as bingo clubs and casinos. The Company owned a portfolio of famous leisure brands including Butlin's holiday camps, Odeon cinemas and Hard Rock Café; and was associated with Universal Studios in theme park joint ventures in Florida and Osaka, Japan. (Whittington and Mayer, 2000; Channon 1973: 62-3, 188-192)

The real momentum in the growth of the conglomerates began in the 1960s, and was intensified in 1970s. It was enabled by the fluid market for corporate control which had opened up after Sigmund Warburg had introduced the concept of the hostile takeover when he facilitated the takeover of British Aluminum in 1956. (Ferguson, 2011: 183-199) During the 1960s the tightly regulated British financial system began to be liberalized, enabling a new range of funding opportunities for acquisitions as the subsequent decade of oil price hikes and extensive industrial strikes weakened long-established firms. They were also weakened by high inflation, while rapidly rising price levels also facilitated the claims of conglomerates to be able to turn around poorly performing firms, as nominal revenues rose sharply.

A new type of financier emerged, engaged in buying and selling companies, and taking advantage of the internationalized financial system. High profile figures included "Jimmy" Goldsmith, who with the financial backing of Isaac Wolfson, bought up a series of bakeries in 1965 and founded Cavenham Foods. He used this a vehicle to buy and asset-strip established firms like Bovril, using a network of private companies and the Cayman Islands-registered 32 
General Oriental Investments, and allied with the controversial finance house Slater, Walker, which eventually went bankrupt in 1975. Although Goldsmith sold many of his diversified investments in the early 1980s, he was immortalized as the distasteful British financier Sir Lawrence Wildman in the classic Hollywood movie Wall Street in 1987. Meanwhile the 1980s with deregulation and liberalization in full swing under Thatcher in Britain and Reagan in the United States, there were many acquisition opportunities for other "corporate raiders" who could finance acquisitions by borrowing from the financial markets and banks, and maintained a selfsustaining earnings growth by the constant accumulation of companies.

Hanson Trust was a classic example. James Hanson, the scion of a long-established family business, and Gordon White, built Hanson Trust into Britain’s ninth largest company by the early 1990s with sales of $£ 10$ billion. It started in 1964 when James Hanson and Gordon White set up a small company called Welbecson which imported greetings cards from the United States. In the following year they took over Wiles Group, a small animal by-products company, sack hire and fertilizer firm, and in 1968 bought a brick maker called Butterley. Hanson Trust was formed in 1969. White settled in New York in 1973 and started building a US business, but Hanson Trust remained a modest affair until the takeover of a struggling British company called Lindustries, which made locks, safes and security equipment, in 1979. There followed a swathe of large acquisitions including the battery maker Berec, the renamed British Eveready in 1982, the Imperial Group in 1986, and Quantum, an American plastics specialist, in 1993. The Imperial Group was bought in 1986 for £2.5 billion, of which Hanson recouped £2.4 billion in subsequent asset sales, leaving Hanson in control of Imperial's large and profitable tobacco operations. Hanson's activities came to include tobacco products, forest products, coal mining, chemicals, 
and bricks and construction. Hanson was closely connected to the Conservative Party, which ruled Britain under Prime Minister Margaret Thatcher during the 1980s, and was made a Lord in 1983. (Brummer and Cowe, 1994)

Hanson grew using a simple business model: buy asset-rich companies, often in lowrisk stable industries such as cigarettes and bricks, with good cash flows and manage them for cash and return on capital. The business was almost entirely based in Britain and United States, reflecting the active markets for corporate control which made acquisitions and asset stripping far easier than in Continental Europe or elsewhere. A key feature of the business model was the payment of as little tax as possible. Until a change in British tax laws in 1987, Hanson employed the device of dual-resident companies - incorporated in the United States but with a trading address in Britain - which enabled the venture to claim tax relief on interest payments in both countries. During the 1980s Hanson had up to twenty companies incorporated in the tax haven of Panama, through which many transactions passed. It was further more complicated in its structure than the usually-assumed conglomerates that wholly owned their subsidiaries. For instance, Kidde, an acquired business of Hanson in 1987, was not only retained as an entity, but it was owned by numerous other Hanson entities, all of them private, and many registered outside the UK. As Figure 1 shows, the ultimate owner, Hanson Trust, was several tiers distant in ownership terms. (Brummer and Cowe, 1994) 
Figure 1. Ownership and control of a Hanson Trust subsidiary, Kidde, in 1987

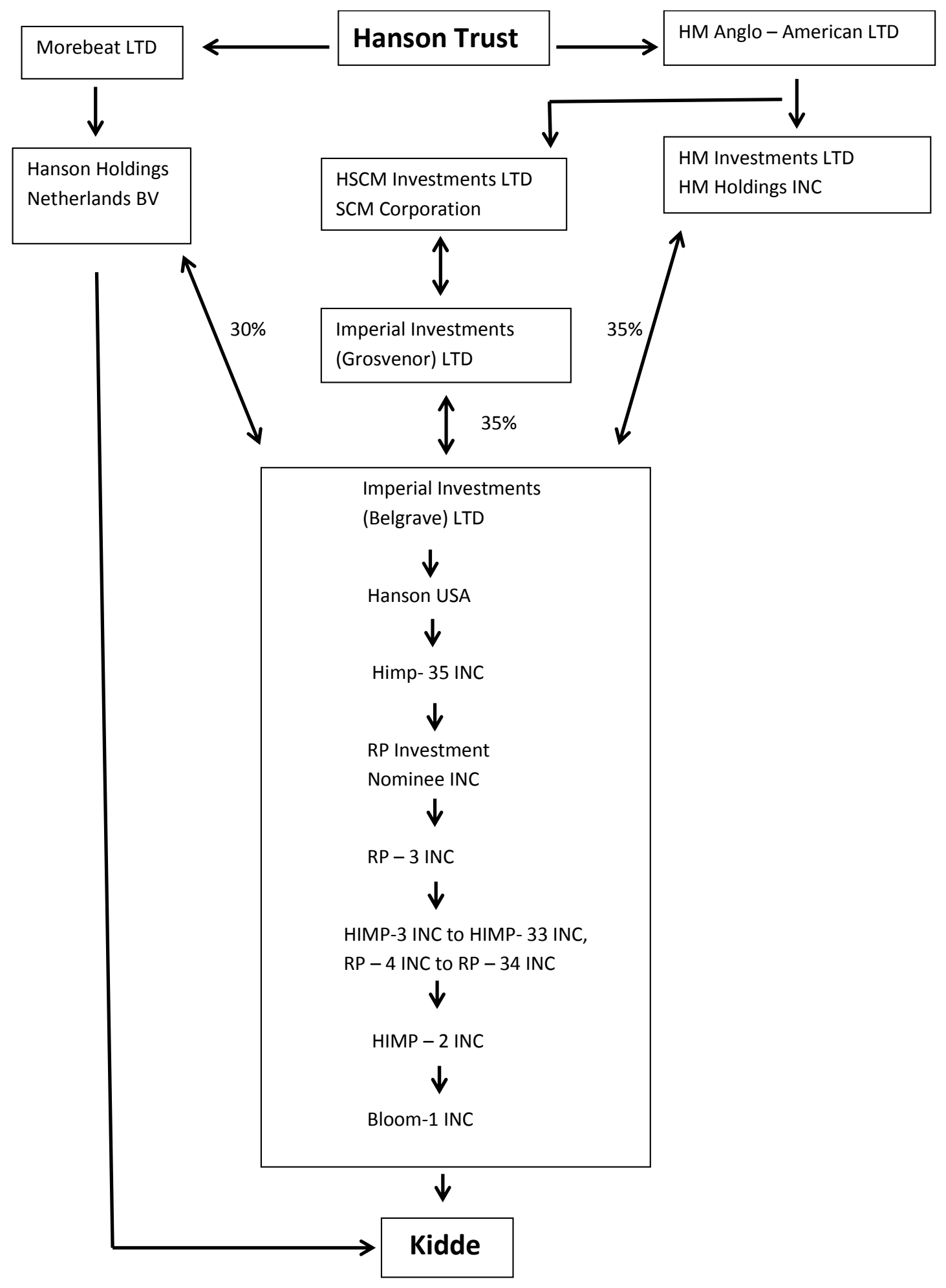


Source: Redrawn based on Brummer and Cowe, Appendix 5, p. 319.

BAT (British American Tobacco) grew out of a single product firm making tobacco products. In 1952 it acquired the paper manufacturer Wiggins-Teape. In 1964 it ventured into entirely new pastures when it acquired both an ice cream company and a one-third stake in the Lenthéric fragrance house, which became wholly-owned within three years. While the ice cream company was divested within four years, BAT's adventures in beauty proved to be more sustained. Over the following two decades BAT spent $\$ 120$ million acquiring small and mediumsized cosmetics and fragrances businesses, usually from the descendants of founding families. Acquisitions included Morney (1966), Yardley (1967), and US-based Germaine Monteil (1969), all of which owned well-established brands which had become tired. During the 1970s major investments in retail were made including the Argos catalogue chain and the Marshall Field's department stores in the United States. In 1984 financial services were added when the firms acquired Eagle Star insurance, followed by Allied Dunbar and Farmers in the United States. Whittington and Mayer, 2000: 141)

BTR grew rapidly from the 1970s from a modest firm in the rubber industry to a diversified industrial conglomerate. This growth was based on a series of acquisitions of oncefamous names in British industry, including Thomas Tilling in 1983, Dunlop in 1985, and Hawker Sidde1ey in 1991. By then the firm had sales of $\$ 11.3$ billion, operated 600 plants worldwide and had subsidiaries in 24 countries, and was one of the ten largest companies on the London Stock Exchange. (Elderkin, 1997, Jones 1997) 
To some (at the time and subsequently) these conglomerates represented the worst excesses of “financial capitalism.” They adopted a particularly decentralized form of organization. Headquarters were often primarily concerned with financial matters; in other matters, managers in divisions were given considerable autonomy, with most production and sales decisions delegated to subsidiaries. While supporters of such conglomerates pointed to their role in disciplining inefficient managements, their critics questioned both their interest in, and their ability to sustain, long-term strategies centered on innovation rather than the payment of high dividends to shareholders.

\subsection{Capabilities and the Decline of the Conglomerates}

The fact that from the late 1990s many of the conglomerates were unwound would support such a view that their organizational capabilities were not sustainable. BAT sold off its diversified businesses. In 1996 Hanson broke itself up into four separate companies focused on tobacco, chemicals, energy, and building materials. In the same period BTR sold off many peripheral activities and restructured itself around four principal global product groups in which the firm held an advantage, either in superior technology or low cost production. In 1999 it merged with Siebe to form Invensys. It subsequently went through years of divestments to avoid bankruptcy, restructured as an engineering and information technology company, and was acquired by France’s Schneider in 2013.

However the view that the conglomerates were dismantled because they were inherently inefficient, although frequently asserted, is not entirely convincing for several reasons. First, Whittington and Mayer have shown that the financial performance of unrelated diversified 
firms in aggregate was quite good. Indeed, the financial performance of individual firms was impressive. BTR, for example, started the 1980s with a return on equity of 21.5 per cent and ended it with an even higher return of 39.3 per cent as it expanded its level of diversification (Whittington and Mayer, 2000: 150-153) In Cassis’s study of the profitability of British, French and German companies for 1987-89, Hanson impressively tops the list of the most profitable British industrial companies with a rate of return of 54.1 per cent, although the use of complex accounting measures raise some questions about the nature of these earnings: BTR was in third place with 36.2 per cent, and another conglomerate, Grand Metropolitan seventh with 28.7 per cent. Hanson and BTR were impressively more profitable than any German or French industrial company in his list. (Cassis 1997:99)

Second, individual case studies point towards real managerial capabilities. Take the apparently odd case of the BAT's acquisitions of small cosmetics and fragrance firms. In 1970 the individual acquisitions were merged into a single subsidiary, British American Cosmetics. A former Procter \& Gamble manager was recruited as managing director. He hired managers from other consumer products companies, rather than the tobacco parent. However synergies were achieved with other parts of the BAT group; in particular, information was shared about consumer marketing and retailing trends at group-wide training sessions. Over two decades a substantial and well-managed business was created out of what had been a random collected of tired brands. There was substantial innovation. Lentheric successfully developed a mass market fragrance business sold through drugstores, and became a market leader in Britain by 1977. BAC slowly grew its business through further acquisitions, although the small size of the business compared to its parent meant that there was a constant struggle to get funds. During the early 
1980s a major restructuring of Yardley, its merger with the more successful Lentheric business, and the creation of a worldwide marketing operation, created a viable and profitable company.

By 1984 BAC was the largest British-owned cosmetics firm, if still a modest player in world terms, which manufactured in 37 countries and sold in over 140, with a product range which spanned fragrances, men’s products, luxury toiletries, make-up and skin care products. The sale of the business in that year was not because it had failed, but because BAT had other priorities. Beauty products never exceeded 2 per cent of overall corporate revenues, one per cent of the profits, of what had become Britain's third largest company by the 1980s. As BAT shifted into financial services, BAC simply did not fit. (Jones 2010: 253-4)

Third, it is noteworthy that the conglomerates left substantive legacies. Take Hanson Trust. This company certainly ran into trouble in the early 1990s through a poorly-managed hostile acquisition attempt at the chemical company ICI. The purchase of this firm would have made Hanson the biggest British company, and secured the hidden jewel within ICI, the pharmaceuticals business that would later become Zeneca. ICI's management, advised by investment bank Goldman Sachs, responded astutely by unearthing some embarrassing facts about Hanson, such the millions of dollars squandered on racehorses by Gordon White. The company's well-deserved aura of maximizing shareholder value was damaged, the company no longer looked like the shareholders' friend, and the whole episode sparked skepticism about the value of the Hanson corporate structure. Yet the successor businesses survived for some time when the firm broke itself up in 1996. The Hanson name went with the building materials company and continued until 2007, when it was acquired by a large German cement company, which ten years later sold to a US private equity firm. And the quality of its management cadre 39 
was demonstrated by the numerous Hanson alumni in senior positions in British industry over the following decade. (Pratley, 2004)

The plausible explanation for the winding up of many of the conglomerates is the same capital market pressures which ended the diversified international business groups: they were simply unfashionable and their share prices came under pressure as a result. Unfashionability resulted in low ratings which raised the cost of capital. Among other things, this made it increasingly hard to find acquisitions could maintain earnings growth. This particularly disrupted the business model of the conglomerates which rested on acquisitions. As the cases of Berkshire Hathaway, News International and GE in the United States showed, stellar returns and charismatic leadership could enable the bullet of the conglomerate discount to be dodged. However the British conglomerates only seem to have made very financial returns rather than stellar ones, and they were short of charismatic chief executives. Lord Hanson came closest in that regard, but the failed ICI acquisition and the horse-racing scandal wrecked his aura of success.

In contrast, the Virgin Group had charismatic leadership, and developed and survived as a diversified business group, holding majority and minority stakes in its companies. The group originated when the 15-year old Richard Branson established a student magazine in 1965. This finally failed, but provided the launch pad for a mail order record business that soon expanded into Virgin Megastore, a chain of popular record stores in Britain. Virgin Records, a lucrative music production business was launched in 1973. In 1984 Branson launched Virgin Atlantic, initially offering a service between London and New York that offered "first class tickets at business-class prices.” The Virgin Group went public in 1987, but Branson soon realized that the 40 
British capital markets were already struggling to understand highly diversified businesses. He took the business private again in 1988.Branson sold the very profitable Virgin Records in 1992, and used the money to expand into new small ventures, including Virgin Cola, Virgin Brides, Virgin Clothing and Virgin Cosmetics. Many failed. There was further diversification in transport. In 1997 Virgin took over the franchise of part of Britain’s rail system and launched Virgin Trains, and in 2000 launched the Australian airline Virgin Blue. The group entered financial services in 1995 when it partnered with an insurance company to create Virgin Direct. In 1998 Virgin backed a start-up team in the health and fitness sector to launch Virgin Active. In 1999 it launched Virgin Mobile, the first British virtual cell phone network operator. Typically, Virgin's start-up model involved the use of private financing alongside another equity investor, combined with a large amount of debt to Virgin Group Holdings, the parent holding company. (Gordon 2014)

The Virgin Group was organized in a hierarchical structure but with some especially distinctive features. In 2014 at least 80 companies had the Virgin name, and a small number of them, including Virgin Atlantic and Virgin Media were large businesses. Virgin Group Holdings, whose portfolio was valued at more than $£ 5$ billion (US $\$ 7.5$ billion) in 2014, fully owned only a few of the companies. The Holdings were run on a private equity model, employing cash or stakes in other firms to support the growth of other Virgin branded businesses. (Gordon, 2014) It held both majority and minority shares in Virgin companies, while other companies were joint ventures. Most of the companies in the portfolio were private, although some like the Australian airline Virgin Australia were publicly listed. Some companies, such as most of the Virgin Mobile companies, were linked to the Group only by a licensing agreement, as Branson had sold all the 
equity. Virgin Mobile Canada, for example, was owned by Bell, and Virgin Mobile Australia was owned by Optus. Virgin controlled the operating companies primarily by having people on their boards and through licensing agreements which stipulated the terms and conditions of the use of the brand. (MacCormack, 2001;Pisano and Corsi, 2012) Table 5 lists the 12 largest Virgin companies by revenues in 2014 and gives their relationship to Virgin Group Holdings.

Table 5 Largest Virgin Companies and relationship to Virgin Group Holdings, 2014.

\begin{tabular}{|c|c|c|}
\hline Virgin Company & Annual Revenues (£ million) & $\begin{array}{c}\text { Virgin Group Holding share of } \\
\text { equity (\%) }\end{array}$ \\
\hline Virgin Media & 4,300 & 0 . Royalty income only \\
\hline Virgin Australia & 2,600 & 51 \\
\hline Virgin Atlantic & 2,600 & 0 Royalty income only \\
\hline Virgin Mobile USA & 1,300 & 22 \\
\hline Virgin Trains & 946 & 48 \\
\hline Virgin America & 911 & Owned by Virgin Atlantic \\
\hline Virgin Active & 631 & 50 \\
\hline Virgin Holidays & 535 & 0 Royalty income only \\
\hline Virgin Mobile France & 362 & 47 \\
\hline Virgin Mobile Canada & 359 & 0 Royalty income Only \\
\hline Virgin Mobile Australia & 343 & \\
\hline Virgin Money UK & 299 & \\
\hline
\end{tabular}

Source: Gordon (2014) 
It remains challenging to describe either the performance or the capabilities of Virgin, as the Group was opaque. The business was intimately connected to the charismatic founder Richard Branson and a brand that symbolized fun, innovation, rebellion, value for money and good customer service. In an interesting twist on organizational design, the brand identity served as the primary means of co-ordinating disparate companies. The Virgin brand also played an important role in recruiting management talent, as the Group was considered an attractive place to work. (Pisano and Corsi, 2012: 8) There were also less flattering explanations of the corporate capabilities which were hard to either prove or disprove. As in the case of other business groups and conglomerates with powerful founder entrepreneurs, such as Tiny Rowland and Lonrho and Rupert Murdoch and News Corporation, there were unproven allegations by some investigative journalists that Virgin's growth rested on actions some might consider as ethically challenging. (Bower, 2008)

It is also possible to see the private equity industry in Britain as a successor to the conglomerates. While the two models differ radically in some respects, including the former's use of independent funds organized as limited partnerships to carry out buyouts rather than holding direct ownership stakes, they also share considerable similarities, including the use of acquisitions and unrelated diversification, and perhaps even, as Cheffins and Armour suggest, “a capacity for capturing the public imagination.” (Cheffins and Armour, 2007:27) The industry association claimed that Britain in 2015 was "one of the leading centers for private equity in the world.” (http://www.bvca.co.uk/AboutUs.aspx, accessed February 15 2015) The largest houses included Apax Partners, which traced its history back to Patricof \& Co. founded in 1969, Permira 43 
(founded 1985), Alchemy Partners (founded 1997), and Phoenix Equity (founded 2001). In 2015 these four ventures had funds under management of $\$ 40$ billion, $\$ 22$ billion, $\$ 2.2$ billion and $\$ 1.3$ billion respectively. However the industry lacked the legitimacy of its American counterpart, and was subject to a British public enquiry in 2007 (Cheffins, 2008: 397-401; De Cock and Nyberg, 2014). The British firms also struggled with serious funding and other issues after the 2008 financial crisis (Ebrahimi, 2013). It remained too soon to tell whether Britishbased private equity firms would recover their dynamism, or eventually follow the path of their predecessors, the conglomerates.

\section{Conclusions}

This working paper has explored the prevalence of business groups, often assumed to be primarily an emerging market phenomenon, in the business history of Britain since 1850. It shows that this form of business organization was by no means been entirely absent, even though the country did not fit the pattern of institutional voids and rent-seeking from autocratic governments frequently associated with the prevalence of business groups in emerging markets

During the second half of the nineteenth century, British merchant houses established business groups with diversified portfolio and pyramidal structures overseas, primarily in developing countries, both colonial and independent. These business groups were often resilient and successful until the late twentieth century. A number, especially Swires and Jardine Matheson, survive today, albeit with their public companies quoted on stock markets outside Britain. In contrast, in the domestic economy, the business group form had a more limited role. Large single product firms were the norm, which over time merged into large combines with 
significant market power. This reflected a business system in which a close relationship between finance and industry was discouraged, but there were few restrictions on the transfer of corporate ownership. Yet some large diversified business groups did develop, typically with substantial international businesses. After World War II, and especially between the 1970s and the 1990s, diversified conglomerates also flourished. Typically both the diversified business groups and the conglomerates were the creation of dynamic entrepreneurs, whether Weetman Pearson, Richard Branson or James Hanson, which developed private or closely held shareholding structures which were resistant to the market for corporate control.

This evidence presented here suggests that diversified business groups can add value in mature markets such as Britain. They proved a successful and flexible organizational form for conducting international business over a long period. In the domestic economy, Pearson and Virgin created well-managed and performing businesses over decades. The much-criticized acquisitive conglomerates were also quite financially successful forms of business enterprise. While capable of major missteps, the demise of many of them appears to owe at least as much to management fads as to serious under-performance. 


\section{REFERENCES}

Barbero, María Inés and Raúl Jacob. 2008. La neuva historia de empresas en Amémica Latina y España. Temas: Buenos Aires.

Bud-Frierman, Lisa, Andrew Godley, and Judith Wale. 2010 "Weetman Pearson in Mexico and the Emergence of a British Oil Major, 1901-1919”, Business History Review, 84: 275-300.

Bower, Tom.2008. Branson, London; Harper Perennial.

Broadberry, Stephen N. and Crafts, Nick F.R. 1992. “Britain’s Productivity Gap in the 1930a: Some Neglected Factors,” Journal of Economic History, 52, 3: 531-558.

Brummer, Alex and Cowe, Roger. 1994 Hanson: The Rise and Rise of Britain's Most Buccaneering Businessman. London: Fourth Estate.

Butler, Charlotte and Keary, John. 2000 Managers and Mantras. One Company's Struggle for Simplicity Singapore: John Wiley.,

Cassis, Youssef. 1997 Big Business. The European Experience in the Twentieth Century. Oxford: Oxford University Press,.

Chandler, Alfred D. 1990. Scale and Scope, Cambridge MA: Harvard University Press. 
Channon, Derek. 1973. The Strategy and Structure of British Enterprise London: Macmillan.

Cheffins, Brian R. 2008 Corporate Ownership and Control. British Business Transformed, Oxford: Oxford University Press.

Cheffins, Brian and Armour, John. 2007. "The Eclipse of Private Equity”, European Corporate Governance Institute Working Paper Series in Law, No. 82/2007.

Chung, Chi-Nien. 2006. “'Beyond Guanxi’: Network Contingencies in Taiwanese Business Groups”, Organization Studies, 27, 4: 461-489.

Colpan, Asli M., Takashi Hikino and James R. Lincoln (eds.) 2010. Oxford Handbook of Business Groups. Oxford: Oxford University Press.

De Cock, Christian and Nyberg, Daniel.2014. “The Possibility of Critique under a Financialized Capitalism: The Case of Private Equity in the United Kingdom,” Organization, published online December 22.

Dunning, John H. and Lundan, Sarianna M. 2008 Multinational Enterprises and the Global Economy. Cheltenham: Edward Elgar.

Ebrahimi, Helia. 2013. "Britain's private equity titans have tumbled” The Daily Telegraph, March 30.

Elbaum, Bernard and William Lazonick (eds.). 1987. The Decline of the British Economy, Oxford: Clarendon Press.

Elderkin, Ken. 1997 “The Takeover of the Norton Company,” Harvard Business School Case 9291-002, rev. December 15.

Ferguson, Niall. 2011. High Financier.London: Penguin. 
Fieldhouse, David K. 1994. Merchant Capital and Economic Decolonization, Oxford: Clarendon Press.

Foreman-Peck, James and Hannah, Leslie. 2012. "Extreme divorce: the managerial revolution in UK companies before 1914,” Economic History Review, 65, 4: 1217-1238.

Fortune, Global 500 (2014)

Franks, Julian, Mayer Colin and Rossi Stefano. 2005. "Spending less Time with the Family: The Decline of Family Ownership in the United Kingdom,” in Randall Morck (ed.) A History of Corporate Governance around the World. Chicago: University of Chicago Press: 581-607.

Garner, Paul. 2011. British Lions and Mexican Eagles. Business, Politics, and Empire in the Career of Weetman Pearson in Mexico, 1889-1919. Stanford: Stanford University Press.

Glete, Jan. 1994. Nätverk i näringslivet: ägande och industriell omvandling $i$ det mogna industrisamhället 1920-1990. Stockholm: SNS Förlag

Gordon, Sarah. 2014 . “Brand it like Branson,” Financial Times. November 6.

Hannah, Leslie. 1976. The Rise of the Corporate Economy, London; Methuen.

Hannah, Leslie. 1980. "Visible and Invisible Hands in Great Britain,” in Alfred D. Chandler and Herman Daems (eds). 1976 Managerial Hierarchies. Comparative Perspectives on the Rise of the Modern Industrial Enterprise. Cambridge, Mass: Harvard University Press,

Hannah, Leslie.2007. “The 'Divorce' of Ownership from Control from 1900 Onwards: Recalibrating Imagined Global Trends”, Business History, 49, 4: 404-438.

Hannah. Leslie. 2009. “Strategic Games, Scale and Efficiency, or Chandler goes to Hollywood,” in Richard Coopey and Peter Lyth (eds.) Business in Britain in the Twentieth Century, Oxford: Oxford University Press. 
Hill, Charles W. L. 1985. "Diversified Growth and Competition: the Experience of Twelve Large UK Firms,” Applied Economics, 17: 827-847.

Iversen, Martin Jes and Mats Larsson. 2011. "Strategic Transformations in Danish and Swedish big business in an era of globalization,” Business History, 53, 1:119-143.

Jones, Geoffrey (ed.) 1986. British Multinationals: Origins, Management and Performance, Aldershot: Gower.

Jones, Geoffrey. 1994. “British multinationals and British business since 1850,” in Maurice W. Kirby and Mary B. Rose (eds.) Business Enterprise in Modern Britain, London; Routledge. Jones, Geoffrey 1997. "Great Britain: Big Business, management and competiveness in twentieth-century Britain,” in Alfred D. Chandler, Franco Amatori and Takashi Hikino (eds.) Big Business and the Wealth of Nations. Cambridge: Cambridge University Press. Jones, Geoffrey 2000. Merchants to Multinationals, Oxford: Oxford University Press. Jones, Geoffrey. 2005a. Multinationals and Global Capitalism, Oxford: Oxford University Press. Jones, Geoffrey.2005b. Renewing Unilever. Oxford: Oxford University Press.

Jones, Geoffrey 2010 Beauty Imagined. A History of the Global Beauty Industry, Oxford: Oxford University Press..

Jones, Geoffrey and Asli M. Colpan. 2010. "Business Groups in Historical Perspectives" in Asli M. Colpan, Takashi Hikino, and James R. Lincoln (eds) The Oxford Handbook of Business Groups, Oxford: Oxford University Press.

Jones, Geoffrey and Asli Colpan. 2016. "Business groups, entrepreneurship and the growth of the Koç Group in Turkey,” Business History, DOI:10.1080/00076791.2015.1044521. • 
Jones, Geoffrey and Andrea Lluch (eds). 2015. The Impact of Globalization on Argentina and

Chile: Business Enterprises and Entrepreneurship. Northampton, MA, United States: Edward Elgar Publishing.

Jones, Geoffrey and Judith Wale. 1998. "Merchants as Business Groups: British Trading Companies in Asia before 1945,” Business History Review, 72: 367-408.

Khanna, Tarun and Yishay Yafeh. 2007. "Business Groups in Emerging Markets: Paragons or Parasites?”. Journal of Economic Literature, 45/2: 331-72.

Kock, Carl, and Mauro F. Guillén. 2001 "Strategy and Structure in Developing Countries: Business Groups as an Evolutionary Response to Opportunities for Unrelated Diversification,” Industrial \& Corporate Change 10 (1): 1-37.

Lindgren, Håkan. 1994. Aktivt Ägande. Investor under växlande konjunkturer. Stockholm: Institute for Research in Economic History, Stockholm School of Economics.

MacCormack, Alan. 2001. “Virgin.com”, Harvard Business School case No. 9-601-041, rev. August 29)

Michie, Ranald. 1999. The London Stock Exchange. A History. Oxford. Oxford University Press. Munro, J. Forbes. 2003 Maritime Enterprise and Empire. Woodbridge: Boydell.

Morck, Randall. 2009. “The Riddle of the Great Pyramids,” NBER Working Paper No. w14858

Owen, Geoffrey. 2009. "Industrial Policy in Twentieth Century Britain,” in Richard Coopey and Peter Lyth (eds.) Business in Britain in the Twentieth Century, Oxford: Oxford University Press. Pisano, Gary and Elena Corsi. 2012. "Virgin Group: Finding New Avenues for Growth,” Harvard Business School Case no 9-661-070 (rev. May 9)

Reingold, Jennifer. 2015. “Everybody Hates Pearson” Fortune January 21. 
Schneider, Ben Ross, "Business Groups and the State: The Politics of Expansion, Restructuring, and Collapse”, 2010. In Oxford Handbook of Business Groups, in Asli M. Colpan, Takashi Hikino and James R. Lincoln (eds.) Oxford: Oxford University Press.

Tripathi, Dwijendra. 2004. The Oxford History of Indian Business, New Delhi: Oxford University Press.

Spender, J.A. 1930 Weetman Pearson. First Viscount Cowdray 1856-1927 London: Cassell.

Pratley, Nils (2004) "Legacy of the lord with the Midas touch,” The Guardian, November 2.

Yacob, Shakila \& Khadijah Md Khalid 2012.“Adapt or Divest? The New Economic Policy and Foreign Businesses in Malaysia (1970-2000),” Journal of Imperial and Commonwealth History, 40, 3.

Whittington, Richard and Michael Mayer, 2000. The European Corporation. Strategy, Structure, and Social Science. Oxford: Oxford University Press,

Wilkins, Mira 1988. “The Free-standing Company, 1870-1914: An Important Type of British Foreign Direct Investment,” Economic History Review, XLI (2): 259-82. 
